\title{
Perfiles históricos de la Argentina rural: agro y política (1880-1970)
}

\author{
Historical profiles of rural Argentina: agro and politics (1880-1970)
}

Perfis históricos da Argentina rural: agro e política (1880-1970)

NoemíM.Girbal-Blacha*

\section{Resumen}

La historia de la Argentina se vincula al medio, la producción y la comercialización rural. Conocer y reconocer sus orígenes pecuarios y mercantiles, asociados a la modernidad agroexportadora, a las limitaciones de la expansión horizontal agraria y a las crisis que inducen la regulación económica por parte del Estado son útiles para el diagnóstico y la comprensión de la situación argentina en el concierto internacional. En este paisaje cambiante los actores sociales agrarios y el Estado, dialogan y discuten, enervando una compleja relación de poderes. Un recorrido histórico crítico, que atienda a los diversos sectores del poder rural, sus relaciones entre sí y entre ellos y el poder político, promueve la reflexión de este estudio, que procura comprender una Nación conformada sobre bases ru- rales, aunque la sociedad posea una frágil memoria sobre aspectos sustantivos de su pasado agrario.

Palabras clave: Agricultura. Politica. Territorio. Argentina.

\section{Planteo del tema}

Desde sus orígenes la historia de la Argentina aparece vinculada en su economía, su sociedad y su sistema político al medio, la producción y la comercialización rural. Primero a la producción y comercio ganaderos

\footnotetext{
Doctora en Historia (Universidad Nacional de La Plata). Investigadora del CONICET y Centro de Estudios de la Argentina Rural (CEAR), Universidad Nacional de Quilmes (UNQ), Argentina. E-mail: noemigirbal@gmail.com
}

Recebido em 17/02/2016 - Aprovado em 28/03/2016 http://dx.doi.org/10.5335/hdtv.16n.1.6251 
y desde fines del siglo XIX a la agricultura extensiva.

Conocer y reconocer sus orígenes pecuarios y mercantiles, asociados a la modernidad agroexportadora, a las limitaciones de la expansión horizontal agraria y a las crisis que inducen la regulación económica por parte del Estado, así como el papel jugado por estas coyunturas en la planificación económica -más o menos unida al dirigismo estatal- son útiles para el diagnóstico y la comprensión de la situación argentina en el concierto internacional.

En este paisaje cambiante pero que no renuncia a sus rasgos tradicionales vinculados al campo, el Estado y los actores sociales en tanto líderes del poder económico agrario, dialogan y discuten, enervando una compleja relación de poderes. Un Estado en ocasiones liberal, en otras intervencionista o benefactor y los sectores hegemónicos agrarios que se identifican o se relacionan con los representantes de ese Estado para recibir protección, exigir subsidios o brindar el respaldo económico de sus productos, son los ejes de la Argentina rural y del poder económico que definen la historia nacional.

Un recorrido crítico y de la mano de la historia, atendiendo a los diversos sectores del poder rural entre sí y entre ellos y el poder político, promueve la reflexión de este estudio, que procura comprender a una Nación conformada sobre bases rurales, aunque la sociedad posea una frágil memoria sobre aspectos sustantivos de su pasado agrario.

\section{Rumbo al Centenario de la Revolución}

$$
\text { de Mayo (1910) }
$$

La República Argentina desdibuja, hacia 1880, su fisonomía pastoril y criolla. Se convierte en un país agropecuario, receptor de capital externo e inmigración masiva que proporciona la mano de obra abundante y barata para modernizarse, afianzado en una sólida alianza entre los importadores, exportadores, ganaderos y oligarquías provinciales, mientras se inserta en el ámbito internacional como proveedor de materias primas agrarias. Son tiempos de liberales en lo económico y conservadores en lo político (MCGANN, 1960).

En la Argentina, la tierra, que con el fin de la lucha contra el indio se concentra en pocas manos, resulta un símbolo de prestigio social, base del poder político y sustento de la producción rural. Su valor intrínseco se suma a: la inmigración (que ante la imposibilidad de convertirse en propietaria alimenta un rápido proceso de urbanización), el capital externo (esencialmente británico y orientado a ferrocarriles y frigoríficos), el comercio internacional (vinculado a Inglaterra), la consolidación del poder político que organiza entonces estructuras de alcances nacionales respaldado por el ejército y el Congreso en medio de la decadencia de las autonomías provinciales. Son éstos rasgos de la Argentina Moderna, conducida por una élite con capacidad de control económico, vinculada al quehacer mercantil y agrario, con espíritu de cuerpo y conciencia de tal (BOTANA, 1979; CARMAGNANI, 1984).

En 1890 se produce el apogeo y crisis del liberalismo y la élite dirigente pierde cohe- 
sión. Cobra cuerpo la expansión de la agricultura cerealera argentina al amparo del ferrocarril y orientada al principal centro de comercialización: la ciudad puerto de Buenos Aires, sustentando la economía agroexportadora de alta concentración en la región pampeana (Buenos Aires, centro sur de Santa Fe, Entre Ríos, sudeste de Córdoba y La Pampa). Basada en el arrendamiento se asocia a la ganadería de alta mestización destinada al frigorífico de capital británico instalado en Buenos Aires en 1883. El monopolio del frigorífico desplaza a los saladeros fuera de su área de influencia (Buenos Aires-La Plata), transforma la típica estancia pampeana, promueve el proceso de desmerinización (reemplazando la oveja merino, productora de lana, por la lincoln, productora de carne), valoriza el vacuno y diversifica la producción ganadera. En la Sociedad Rural Argentina (creada en 1866), confrontan criadores e invernadores.

El valor de la tierra aumenta y los altos precios internacionales pagados por los cereales dan sus frutos. La cerealicultura adquiere significado propio en el conjunto de la economía y en la balanza comercial del país. La Argentina - con un mercado interno acotado y casi la totalidad de su producción destinada a la exportación -, ocupa los primeros puestos junto a Rusia y los Estados Unidos en la provisión de granos al mercado mundial.

La gran propiedad y la generalización del arrendamiento son los extremos de un amplio espectro socio-rural con alta incidencia en la ocupación del espacio regional pampeano y que integran, en la cúpula: grandes propietarios absentistas, terrate- nientes, arrendatarios de grandes extensiones (todos ellos dedicados a la ganadería de alta mestización), y como sectores subalternos: chacareros, pequeños y medianos arrendatarios, aparceros y peones de cosecha. Entre el circuito productivo y el de circulación de la producción agraria, se sitúa el almacenero de campaña, proveedor del crédito informal y eslabón imprescindible para la comercialización. Todos ellos hacen posible la presencia de una agricultura extensiva cerealera y forrajera, que rota con facilidad entre la producción agrícola y la pecuaria, en medio de un sistema comercial concentrado (Bunge y Born, Louis Dreyfus y Co., Otto Bemberg, Huni-Wormser) y sin un embarque a granel, con escasez de galpones, de elevadores terminales y de campaña (SCOBIE, 1968; HORA, 2003).

Son estas características del boom agrícola que vive la pampa húmeda hasta los inicios de la década de 1910, las que perfilan un país moderno que asiste a los conflictos agrarios de chacareros (aparceros) y peones de la región. Los sucesos del Grito de Alcorta (Santa Fe) de 1912, reclamando contratos de arrendamiento más duraderos, libertad para comercializar la cosecha y baja en los cánones de arriendo, muestran el enfrentamiento entre grandes propietarios y arrendatarios. El resultado duradero del conflicto es la conformación de un organismo corporativo que los representa: la Federación Agraria. Paralelamente -desde los albores del siglo XX- se vive la "edad de oro del frigorífico" (ORTIZ, 1964), cuando en medio de la aftosa, denunciada por los ingleses, se interrumpe la exportación de ganado en pie. Los británicos protegen sus inversiones. Aunque un par de 
años más tarde, el ingreso del trust de Chicago al negocio de las carnes enfriadas y su producción de chilled beef, los obligue a competir y a firmar en 1911 el primer acuerdo que fija cupos de embarque según el origen de los establecimientos. Los británicos siguen conservando la propiedad de los barcos frigoríficos, dirigen las aseguradoras y Smithfield sigue siendo el gran mercado de recepción de las carnes enfriadas y congeladas procedentes de la Argentina (SMITH, 1968).

Mientras la pampa húmeda es todo un símbolo del progreso agropecuario, en el interior no ocurre lo propio. La conformación del Estado y del mercado nacional, con su sistema de alianzas, obliga a las economías regionales a efectuar cambios para participar de las exigencias de la Argentina agroexportadora, que desde el poder político y económico crece con la mirada puesta en Europa. La llegada del ferrocarril, el crédito oficial barato y la protección estatal diseñan, de común acuerdo con las burguesías locales, modelos de monoproducción: el azúcar con epicentro en Tucumán (NOA) y vitivinicultura en la región de Cuyo. Mientras tanto, las regiones marginales de la Patagonia, en el extremo sur, y el Nordeste argentino se insertan tardíamente - explotando sus recursos naturales - al modelo agroexportador. La agricultura se convierte en el común denominador de la economía argentina, trascendiendo las especificidades regionales.
Cuadro 1 - Crecimiento desigual en la Argentina Moderna, 1912 (\%)

\begin{tabular}{|l|r|r|r|r|r|}
\hline \multicolumn{1}{|c|}{ Región } & $\begin{array}{r}\text { Extens. } \\
\text { territ. }\end{array}$ & Poblac. & Agricult. & Ganadería & FFCC \\
\hline Norte & 25,7 & 16,5 & 4,6 & 13,1 & 16,0 \\
Andina & 17,6 & 9,5 & 4,1 & 4,9 & 9,5 \\
Litoral-centro & 27,7 & 72,7 & 90,5 & 70,1 & 73,0 \\
Patagónica & 28,9 & 1,2 & 0,7 & 12,7 & 1,5 \\
\hline
\end{tabular}

Fuente: Ministerios del Interior, Relaciones Exteriores y Agricultura. Anuario Oficial de la República Argentina. Primer año-1912. Buenos Aires, 1912. p. 50.

Apenas iniciada la década 1910, en medio de los festejos del Centenario de la Revolución de Mayo, se llega al fin de la expansión horizontal agrícola. La agricultura extensiva está jaqueada. Es difícil sostener su crecimiento con los desajustes del modelo agroexportador.

Cuadro 2 - Superficie cultivada, 1888-1930

\begin{tabular}{|r|r|r|r|}
\hline Año & \multicolumn{1}{|c|}{$\begin{array}{c}\text { Hects. } \\
\text { sembradas }\end{array}$} & $\begin{array}{c}\text { Cereales y lino } \\
(\%)\end{array}$ & \multicolumn{1}{c|}{$\begin{array}{c}\text { Forrajeras } \\
(\%)\end{array}$} \\
\hline 1888 & 2.459 .120 & 65,7 & 15,8 \\
1895 & 4.892 .004 & 75,2 & 14,3 \\
1900 & 6.427 .417 & 73,1 & 19,7 \\
1910 & 18.290 .419 & 65,0 & 29,5 \\
1914 & 22.193 .190 & 61,4 & 33,3 \\
1920 & 22.131 .106 & 56,3 & 38,2 \\
1925 & 23.908 .719 & 68,9 & 25,2 \\
1930 & 27.195 .855 & 73,5 & 21,0 \\
\hline
\end{tabular}

Fuente: Comité Nacional de Geografia (1941, p. 203-204); Ortiz (1964, p. 232).

Desde comienzos del siglo XX y hasta 1914 , los productos agrícolas rondan el $52 \%$ sobre el valor total de las exportaciones. La Argentina se ubica entre los primeros pro- 
veedores cerealeros mundiales, amparada en las ventajas comparativas del agro argentino. También en la ganadería la posición de la Argentina con respecto a sus similares de Australia y Nueva Zelandia, es óptima y responde a las expectativas del boom agropecuario.

\section{Del Centenario a la crisis}

Como una expresión del balance del Centenario, se consolida la Argentina de los partidos políticos modernos, que expresan una participación ampliada incorporando a los sectores medios al tablero político, de la mano del policlasista partido radical (UCR), representativo de la exigencia de control económico por parte de las provincias. De todos modos, se muestra un consenso favorable hacia el modelo. Sólo se proponen reformas moderadas en la redistribución del ingreso. El énfasis está puesto en la democracia, el nacionalismo hermanado con la tradición y la presencia de un Estado árbitro en las cuestiones económicas y sociales (ROCK, 1997). La integración política entre grupos terratenientes y sectores medios urbanos, es el principal desafío que debe afrontar el radicalismo en el poder, dispuesto a mantener la estructura socioeconómica y promoviendo una más amplia participación política. El primer gabinete que acompaña a Hipólito Yrigoyen en su gestión gubernativa desde 1916, es una manifestación de ese propósito: 5 de sus 8 ministros son ganaderos bonaerenses, miembros de la Sociedad Rural, o vinculados al poderoso sector exportador. La lucha por el control partidario resulta inevitable y en 1924 se traducirá en la división del partido (SMITH, 1968).

En 1914, a las dificultades derivadas del fin de la expansión horizontal agraria se suman las de la Primera Guerra Mundial, con la dificultad para disponer de bodegas suficientes destinadas al embarque de granos, se agrega la ventajosa competencia - en términos de distancia e infraestructura - que le hacen los Estados Unidos y Canadá en el mercado internacional granero, así como los cambios en el tipo de carne que se embarca (el enfriado vuelve a dar paso al congelado) para adecuarse a las exigencias coyunturales de los mercados consumidores. La Guerra que deteriora el volumen y el valor de las importaciones con beneficios no buscados para nuestra balanza comercial, acentúa un incipiente proceso de industrialización por sustitución de importaciones, mientras el Estado adopta medidas bancarias de emergencia. El agro se reajusta, rotando en la explotación entre ganadería y agricultura, que aumenta el precio de la tierra destinada a fines pecuarios. A causa de la dificultad para comercializar los cereales, se acentúa hasta 1921 el descenso del área sembrada con ellos, cuando y en relación con el auge del congelado, se incrementa la superficie alfalfada. Se inicia la desaceleración del crecimiento en la economía argentina, que se prolonga hasta la superación de los ribetes más agudos de la crisis orgánica de 1930.

En la región de la pampa húmeda, la traslación de la producción agrícola hacia la pecuaria por parte de los grandes productores, reactiva el malestar de los agricultores arrendatarios, quienes desde 1918 e impulsados por la Federación Agraria Argenti- 
na, reclaman la tierra para quien la ocupa y la trabaja. Para lograr sus objetivos no dudan en asociarse circunstancialmente al movimiento anarquista (F.O.R.A.). Lo hacen en 1920 para presionar al Estado y obtener -con todas las imperfecciones derivadas de su aplicación- la ley de arrendamientos rurales (11.170) de 1921 - varias veces modificada que rige las pautas de contrato para superficies arrendadas que no excedan las 300 hectáreas. Una legislación que abre el rumbo a sucesivas pero escasas conquistas obtenidas por la Federación chacarera (GIRBAL-BLACHA, 1988).

Los efectos de la Primera Guerra Mundial sobre la economía argentina se suman al traslado del centro financiero mundial de Londres a Nueva York. La crisis ganadera de postguerra (1921-1924) se precipita cuando los contendientes europeos vuelven a la normalidad. La Argentina agroexportadora intenta retomar el camino de preguerra con resultados oscilantes, introduciendo las menores reformas posibles al sistema vigente. La sobreinversión en el sector pecuario durante la etapa de la conflagración europea hace crecer el número de cabezas vacunas de 25,8 millones en 1914 a 37 millones en 1918, con una concentración de más del $80 \%$ en la pampa húmeda. Entre 1914 y 1929 el ganado refinado incrementa su valor de 37 a $55 \$$ y el interés por invertir en el sector se refuerza y aumenta el precio de la tierra (SMITH, 1968).

En 1921 se confirma el cambio de exigencias de los mercados compradores. El congelado vuelve a dar paso al enfriado. Los sectores vinculados al congelado no pueden colocar el stock ganadero acumulado y los precios caen. El refrigerado, y con él los invernadores, recobran importancia y se aprestan a recuperar el espacio perdido. La Sociedad Rural Argentina - en nombre de los intereses que representa - reclama protección al Estado nacional. Es el Presidente radical Marcelo T. de Alvear, hombre vinculado a los altos intereses agropecuarios de la pampa húmeda, quien acciona frente al problema, comprometiendo la intervención estatal. En 1923 cuatro leyes intentan responder a la crisis ganadera. La fundamental para superar la crisis establece un precio mínimo para la venta de ganado con destino a exportación y un precio máximo para la venta local de carne. La negativa de los frigoríficos a comprar carne a un precio mínimo pre-establecido, no se hace esperar; en un mercado saturado de animales que no encuentran colocación conveniente, siendo el frigorífico o el mercado interno las únicas opciones de venta. La ley debe ser suspendida por el Ejecutivo Nacional, quien no puede dar solución a la crisis y paga un alto costo político.

La influencia del trust frigorífico entre 1924 y 1930 es indiscutible y genera contradicciones en la economía agropecuaria argentina, cuando se produce -como se dijo- la escisión en el partido gobernante. Desde la Sociedad Rural Argentina hacia 1927 se propone comprar a quien nos compra, en directa alusión a su rechazo hacia los nexos comerciales con Estados Unidos, cuyos frigoríficos lideran el mercado de las carnes enfriadas en el país. Los ganaderos argentinos refuerzan su histórica conexión con el mercado y los inversores ingleses y el 8 de noviembre de 1929 se firma el Pacto anglo-argentino 
D’Abernon. Se conviene allí un crédito recíproco de 100 millones de pesos para facilitar el intercambio entre ambos países durante dos años. La crisis frustrará su ejecución y la alianza se formalizará, sobre otras bases, en 1933 cuando se firme el Tratado Roca Runciman. En 1930 las exportaciones argentinas con destino a Inglaterra representan el 40,5\% del valor total, mientras las destinadas a los Estados Unidos caen de un 23,4\% en 1915 a un 10,7\% en 1930 (SMITH, 1968).

La agricultura en la posguerra recupera el espacio perdido. Desde el Estado se renueva, con escaso éxito, la presentación de proyectos de colonización agrícola y se alientan incentivos a la producción mixta a través de la granja, la huerta y la educación rural. El propósito es radicar a la familia en el campo, sin modificar el sistema de tenencia de la tierra basado en el arrendamiento.

La ley de arrendamientos de 1921, el aumento de los préstamos hipotecarios a partir de la reforma de la Carta Orgánica del Banco Hipotecario Nacional en 1919, la consolidación del crédito agrícola, la sanción de la ley de cooperativas (11.380) de 1926, la fijación de tipos de cereal standard para mejorar la calidad del producto, la conformación de una red nacional de elevadores de granos, acompañan este avance, aun en medio de la competencia del mercado cerealero internacional. A partir de 1926 las cotizaciones mundiales del trigo y desde 1928 las del maíz, decaen. Los precios de los productos agrícolas de exportación descienden en un 64\% entre 1928 y 1932 (O'CONNELL, 1984). El Estado se preocupa por desactivar la cuestión agraria sin alterar el sistema de tenencia de la tierra.
En un marco sociopolítico complejo y heterogéneo, toman posición destacada los representantes del nacionalismo de élite y se consolida la participación política del Ejército. Los protagonistas de la expansión agraria argentina: Estado, chacareros y terratenientes, readecuan sus roles, para ajustarse a las nuevas condiciones de la Argentina agroexportadora. Lo hacen sin renunciar a sus bases tradicionales pero con matices nuevos, entre los cuales se destaca la inserción de los ingenieros agrónomos y economistas en el proceso productivo. La función del agrónomo ya no es sólo económica; tiene una misión social en el campo argentino, enlazada a la necesidad de arraigar al hombre rural y a su familia a la tierra que trabajan. Convencerlos que "el campo es bueno, sano y provechoso", es la misión que se le asigna a este "grupo superior de hombres de ciencia" que habrá de integrar la burocracia técnica en tiempos del Estado interventor. La cúpula del poder económico se pone en guardia. El Estado refuerza su arbitraje y los productores se ajustan al "fin del crecimiento hacia afuera" (GIRBAL-BLACHA, 2000).

La producción agrícola sigue representando en 1930 un 58,6\% del valor total de nuestras exportaciones. En la Tercera Conferencia Económica de 1928 auspiciada por la Confederación Argentina del Comercio, la Industria y la Producción (CACIP, creada en 1916) -que nuclea a las diversas corporaciones productivas del país- se expresa que "la ganadería y la agricultura, con ser la más sólida base de nuestra riqueza, no puede constituir un programa económico integral" (CACIP, 1928, sin página). Un juicio de valor capaz de simbolizar toda una síntesis de 
la Argentina agroindustrial que prosperaría durante los años '30.

\section{El agro y el respaldo del Estado interventor}

El crack internacional de 1929 induce cambios en las condiciones de desarrollo, agravando el convulsionado panorama interno hacia 1932. La crisis se exporta desde Wall Street a los países del área capitalista desarrollada y periférica. Se impone la diplomacia del dólar, que consolida los nacionalismos económicos, realinea el mercado mundial y acentúa la caída de los precios de los productos primarios. El Estado liberal entra en crisis, se activa la polarización social y se derrumba el mercado de capitales (MADDISON, 1988).

La crisis orgánica argentina impregna todos los planos del quehacer nacional, incluyendo el político-institucional. La Argentina padece una crisis de identidad, que lleva a un cuestionamiento de la sociedad hacia la dirigencia, por su incapacidad para dar respuestas a los desajustes del modelo. Sufre - además - una crisis de dependencia vinculada al crecimiento hacia afuera y genera respuestas de adaptación a las exigencias externas. A ellas se agrega una crisis de distribución que agudiza los problemas sociales entre los sectores dirigentes y los sectores bajos de la sociedad y también al interior de la propia dirigencia. Por último, las crisis de participación y de legitimidad, que completan la multicausalidad del fenómeno, indican la ineficacia del sector dirigente para resolver dentro del sistema los problemas nacionales, optando por respuestas cada vez más autoritarias, que llevan a la ruptura del orden institucional y al uso del fraude para legitimarse. Como expone Waldo Ansaldi:

[...] el drama reside tanto en la incapacidad de la clase dominante (burguesía terrateniente) para se dirigente, cuanto en las subalternas para construir un sistema hegemónico alternativo (ANSALDI; MORENO, 1989, p. 68).

Esta crisis orgánica no alcanza a transformarse en crisis revolucionaria, y deja al descubierto a un sector dirigente que mantiene pendiente viejos problemas y no alcanza a responder los emergentes. Se manifiesta el agotamiento histórico de una etapa del desarrollo argentino. La reorganización jurídico-institucional coloca al Ejército en la cúpula del poder político. El país alienta el bilateralismo en favor de Inglaterra, las oportunidades alternativas como la industria y busca grupos económicos más diversificados con estrategias empresariales más cercanas al capital comercial o financiero que al productivo. Reglas de juego que replantean las relaciones entre la sociedad y el Estado, mientras la dirigencia se preocupa más por el equilibrio que por la transformación.

A la sombra de la crisis de 1930 el Estado argentino readecua su papel y el golpe militar del 6 de setiembre de 1930 resulta una respuesta a la frustración de expectativas, más que a una situación de miseria profunda o de mantenimiento del statu quo. La crisis golpea con dureza al sector agrario en medio de un retraso en la tasa de crecimiento, que disminuye el valor de las exportaciones. En 1931, con la depreciación de la moneda (un $40 \%$ ) por la transferencia de capitales al exterior, se implanta el control de cambios, 
que selectivamente frena las importaciones generando el traslado de ingresos desde el sector agrícola al industrial que produce con materias primas nacionales. La agricultura y la ganadería disminuyen su participación en el ingreso nacional, que en 1926 era de un $27,5 \%$ y en 1933 desciende al 25,8\%, en tanto la representación fabril se incrementa de un $17,2 \%$ a un $18,6 \%$ para igual período. La recuperación de la depresión de los años ‘30 es financiada por la transferencia de ingresos de los sectores rurales a los urbanos.

En 1933 se hace evidente la declinación en los precios de los cereales y el 28 de noviembre se crea la Junta Reguladora de Granos para tonificar el mercado agrícola. El objetivo, como el de otras Juntas similares: de carnes, de azúcar, de vino, de yerba mate, es regular la comercialización de la producción, evitar ventas precipitadas, mantener el nivel interno de los precios en beneficio de los productores y fijar oficialmente las cotizaciones para comprar a precios redituables para el productor y vender al exterior al precio del mercado internacional. El Estado subsidia una vez más al agro y los productores se amparan en los alcances de esa benéfica política (GIRBAL-BLACHA, 2000).

Al mismo tiempo se promueve la construcción de elevadores de granos y el embarque a granel (Red General de Elevadores de Granos, 1932), se dispone la tipificación de cereales sobre standards y se organiza el crédito para los agricultores. En 1935 la Argentina ocupa el primer puesto entre los exportadores mundiales de trigo. Entre 1930-1934 los productos agrícolas representan el 59,8\% del valor total de nuestras exportaciones. El agro pampeano recibe los beneficios de estas buenas cotizaciones hasta 1937. Desde 1938 una nueva caída en los precios reactiva el accionar de la Junta Reguladora de Granos.

La crisis de los años ‘30 también obliga a revisar el débil sistema bancario argentino. En 1935 se crean el Banco Central de la República Argentina (ley 12.155) con un capital mixto de 30 millones de $\mathrm{m} \$ \mathrm{n}$ (10 millones suscriptos por el gobierno) destinado a ajustar la oferta de moneda a la demanda, y el Instituto Movilizador de Inversiones Bancarias (ley 12.157) para movilizar los activos fijos. El objetivo es evitar fluctuaciones de la actividad económica interna derivadas de la coyuntura externa. Mientras tanto, la Segunda Guerra Mundial acelera - desde 1939 - el proceso de industrialización por sustitución de importaciones. El dislocamiento del comercio internacional, el asentamiento industrial (21\% del PBI), la inflación de precios frente a un mercado recesivo en bienes disponibles, terminan por provocar un aumento del ahorro interno con una balanza comercial positiva ante la reducción de las importaciones.

Los productos agrícolas son los más afectados por la Gran Guerra ante la falta de bodegas y la mejor situación de nuestros competidores (Canadá y los Estados Unidos). Al iniciarse la conflagración la superficie sembrada en la Argentina alcanza los 28.360 .700 hectáreas, dedicadas en más de un $73 \%$ a cereales; en 1945 se reduce a 26.186.000 hectáreas, con un descenso en la superficie cerealera en beneficio de las forrajeras, producto de la mejor situación de las carnes en el comercio externo argentino (GIRBAL-BLACHA, 2000). 
El Estado se apresta a sostener -una vez más- los precios de los granos, mientras los arrendatarios rurales denuncian desde la Federación Agraria Argentina - en 1936 - violaciones a la Ley Contractual Agraria - reformada en 1932 - por parte de los propietarios de tierras. En 1942, la ley 12.77 reduce obligatoriamente el monto en dinero y/o en especie, de los arriendos y suspende los desalojos, para evitar éxodos masivos de la población rural, preservando el aparato productivo. Los precios agrícolas internos requieren la intervención de la Junta Reguladora de Granos que reinicia las compras de trigo en noviembre de 1940. En el caso del maíz, el Estado auspicia su uso como combustible sustitutivo del carbón y alimento de porcinos. La conflagración favorece la expansión de las oleaginosas como el girasol. El fin de la guerra renueva las esperanzas del sector, que sólo se concretarán después de 1950, con la tecnificación y la "segunda revolución agrícola” (COSCIA, 1984). Se pasa a unidades más grandes y la producción se concentra en una cantidad menor de explotaciones.

Los sectores agrarios se organizan en corporaciones diferenciadas que los representan. A las tradicionales Sociedad Rural Argentina (1866), la Bolsa de Cereales (nacida en 1854 como Sala de Comercio Once de Septiembre) y la Federación Agraria Argentina (1912) se suman ahora la CAP (1934, Corporación Argentina de Productores de Carnes) y en 1932 los criadores nucleados en la CARBAP (Confederación de Asociaciones Rurales de Buenos Aires y La Pampa). En todos los casos procuran aumentar sus márgenes de influencia ante el Estado. La Argenti- na rural se corporativiza mientras se ajusta a las nuevas exigencias mundiales.

La ganadería se recupera de la crisis de 1930 más rápidamente que la agricultura. Su destino más importante - y casi exclusivo es el Reino Unido; un comercio que es altamente dependiente de convenios bilaterales. Son los sectores ganaderos quienes solicitan al Estado la creación de un organismo que represente sus intereses ante los vaivenes externos. Se crea entonces la Junta Nacional de Carnes como organismo autárquico que ejerce el control del comercio de carnes y clasifica el producto. El conflicto ya no compromete sólo a criadores e invernadores, se traslada al sistema político.

Los intereses de la industria ganadera argentina históricamente ligados a los del sector exportador que opera con el mercado británico de Smithfield, expone su poder cuando en las Conferencias de Ottawa de 1932 el Reino Unido fija restricciones a las cuotas de importación sobre productos cuyo origen no fuera el de los dominios británicos. Los ganaderos argentinos temen perder el mercado inglés, receptor de un $90 \%$ de nuestras exportaciones de carnes. La presión de los estancieros para modificar la política comercial argentina cobra cuerpo, mientras los ingleses propician - y obtienen en 1933 - el descongelamiento de fondos fijado por el control de cambios desde 1931 (SMITH, 1968). El Tratado Roca-Runciman de 1933, impulsado por invernadores, frigoríficos y grandes criadores en medio de la oposición parlamentaria y nacionalista, da consistencia a esos reclamos unilaterales. Una vez más, el Estado protege al poder agrario. 
En 1940 la dirigencia nacional alienta cambios estructurales para el mercado interno. El Ministro de Hacienda Federico Pinedo, presenta ante el Congreso Nacional - anticipándose a los temidos efectos de la posguerra - el Plan de Reactivación de la Economía Nacional. Un plan pro-aliado, emanado del Estado para modificar parcialmente la estrategia de desarrollo económico vigente, procurando conciliar industrialización y economía abierta, mientras fomenta el comercio con los Estados Unidos y crea un mercado de capitales. El objetivo central es sostener la adquisición por parte del gobierno de los saldos exportables agrícolas no colocados, manteniendo abierta la economía y oficializando la industrialización. De todos modos, el agro sigue siendo "la gran rueda de la economía" y la industria actuaría como un engranaje secundario, cuyo funcionamiento sería activado cuando aquélla tuviera dificultades (LLACH, 1984). El tránsito del intervencionismo al dirigismo estatal avanza. La falta de apoyo político hace naufragar el plan propuesto, pero deja al descubierto el ascenso del mercadointernismo entre los empresarios, militares, obreros e intelectuales.

El Plan Pinedo de 1940 y la economía política mercadointernista del peronismo originario fueron dos momentos culminantes del gran debate sobre el desarrollo económico nacional (LLACH, 1984, p. 515).

Frente a estos cambios los sectores agrarios se reorganizan y el 24 de febrero de 1943 se funda Confederaciones Rurales Argentinas (CRA). Más allá del frustrado Plan Pinedo, el país sigue esperando la vuelta a la normalidad y pondera el mercado inter- no, que alcanzaría su máxima expresión en tiempos del peronismo. Un balance de los hechos ocurridos entre 1930-1943, muestra la vigencia de una política de contraste. Por un lado el propósito, alentado desde el poder, es restaurar la hegemonía agroexportadora. Por otro, se destaca la creciente importancia del sector industrial en medio de bajas tasas de inversión. En todo el período hay dos grandes sectores sociales ausentes, paradójicamente los más desarrollados con las nuevas condiciones económicas: la burguesía industrial y la clase obrera; sin representación en ninguna de las fuerzas políticas actuantes en la Argentina de entonces.

\section{El valor estratégico del agro en tiempos del Estado Benefactor}

El triunfo de Juan Domingo Perón líder programático de los golpistas de 1943 - en las elecciones presidenciales de febrero de 1946, profundiza la propuesta de una economía mercadointernista y puesta al servicio de amplios sectores populares, a quienes Juan Perón impulsara desde la Secretaría de Trabajo y Previsión Social en noviembre de 1943.

Una política económica conducida por un Estado nacionalista y popular, dirigista y planificador, capaz de concretar la redistribución del ingreso en favor de la pequeña y mediana industria que produce para ese mercado interno, es la que se implementa en la Argentina acreedora de postguerra. La alianza entre los sectores nuevos de la burguesía industrial y la clase obrera organizada, con garantía estatal, definen al gobierno de Juan Perón. Cambia parcialmente el siste- 
ma de intereses económicos dominantes y la estructura de poder existente, para solucionar las crisis de dependencia y distribución.

El Estado peronista afirmándose en la doctrinaria y pendular tercera posición, se orienta a consolidar la autonomía económica del país para construir una Nación socialmente justa, económicamente libre y políticamente soberana. La crisis de dependencia es afrontada por el Ejecutivo Nacional nacionalizando - a partir de 1947 - los servicios públicos (ferrocarriles, teléfonos, gas, usinas eléctricas, flota fluvial) y repatriando la deuda externa, que concreta en 1952. Para remontar la crisis de distribución utiliza la reforma financiera de 1946 que estatiza la banca, considerando patrimonio nacional el capital del Banco Central de la República Argentina, y nacionaliza los depósitos para dar al Estado libertad de acción monetaria y crediticia. El Consejo Nacional de Postguerra, primer organismo argentino de planificación desde 1944, efectúa un diagnóstico socioeconómico y eleva al rango de entidad autárquica al Instituto Argentino para la Promoción del Intercambio (I.A.P.I.) que desde 1946 monopoliza el comercio exterior argentino para ejecutar la redistribución del ingreso.

Estos instrumentos financieros, económicos y políticos, habilitan los objetivos del Primer Plan Quinquenal (1947-1951). Los sectores agrarios productores y comercializadores, soportan el mayor peso del cambio, pero sin ser apartados de los beneficios de un conveniente crédito oficial. Hasta 1949 se extiende la expansión económica y - a pesar de las advertencias del discurso oficial - el sector rural juega un papel estratégico. Dis- cusiones, confrontaciones y acuerdos signan el diálogo entre el Estado - empeñado en tomar distancia de la Argentina agroexportadora sin prescindir de ella - y los diversificados actores agrarios, dispuestos a responsabilizar al gobierno de los desfasajes del sector rural. La política agraria desplegada, tanto antes como después de 1950, se nutre de controversias y acuerdos que siempre refuerzan el protagonismo de este sector productivo en la economía del país.

En noviembre de 1943, el decreto 14001 concede una rebaja obligatoria del $20 \%$ en el precio vigente para los arriendos, buscando paliar la difícil situación financiera; al mismo tiempo mantiene en vigencia la prórroga de contratos y la suspensión de los juicios de desalojo fijados por la ley 12771 de 1942. La Federación Agraria considera que está a las puertas de lograr la tierra para quien la ocupa y la trabaja, impulsada por el Consejo Agrario Nacional (creado en 1940) mediante algunas expropiaciones en territorios de regular productividad. Desde el capítulo XI del Manual del peronista se proclama que "el que tenga la tierra ha de laborarla; y el que no pueda pagar peones, debe trabajarla personalmente. Por otra parte, si no es capaz de trabajarla, que la venda" (MANUAL..., 1948, p. 30). La estrategia parece anunciar una reforma agraria, pero en realidad impulsa - sin desearlo - un proceso de desinversión en el agro, debido a las prórrogas en los contratos de arrendamiento; ante un escaso compromiso de arrendatarios y propietarios para reinvertir parte de su renta en el campo, del cual no pueden disponer libremente. El oficialismo pretende mantener el equilibrio intersectorial entre propietarios, arrendatarios y ex- 
portadores, para evitar un desgaste político y la puesta en tensión de todo el sistema agrario.

La proliferación de sociedades anónimas agrarias, inmobiliarias, constituidas desde mediados de los años 40, con la participación de familiares de los propietarios originales indican que se ha iniciado la aceleración del proceso de fraccionamiento de grandes propiedades rurales en explotaciones medianas, a través de esa argucia que, por un lado las exime del pago del impuesto a la herencia y, por otro, les permite conservar la propiedad a través de acciones innominadas. Las expectativas de los diversos actores sociales rurales frente al accionar del gobierno peronista, se acrecientan. Todos esperan definiciones. El Estado intenta satisfacer las necesidades de un electorado rural importante (31\% del total de votantes).

El Estatuto del Peón Rural de 1944 que reglamenta las condiciones laborales de los asalariados agrarios permanentes, el Estatuto del Tambero-Mediero de 1946, la atención prestada al Centro de Oficios Varios que sindicaliza a los peones estacionales o transitorios, así como la propuesta de reforma agraria sustentada por el Consejo Agrario Nacional, no crecen con el ascenso de Juan Perón al gobierno nacional, quien se empeña en recordar que: "la tierra no debe ser un bien de renta, sino un bien de trabajo" (MANUAL..., 1948, p. 30).

Si el discurso suena amenazante, los hechos muestran acuerdos. La titularidad de la cartera de Agricultura entre 1946 y 1947 queda en manos del hacendado Juan Carlos Picazo Elordy, con intereses agropecuarios y hombre de la poderosa Sociedad Rural
Argentina. También su sucesor, el ingeniero agrónomo Carlos Alberto Emery, pertenece a la Asociación Criadores de Ganado Holando Argentino. En todos los casos, las reformas sociales para los sectores más bajos del campo, son presentadas por el Ejecutivo Nacional como indispensables para amortiguar los conflictos de la empresa agraria. La oscilación entre disensos y acuerdos permite al gobierno federal recortar las atribuciones del Consejo Agrario Nacional. Se inicia la etapa de controlar los cambios (LATTUADA, 1986).

La planificación económica peronista alienta una producción agropecuaria creciente para minimizar el conflicto social y alentar - sobre bases genuinas - la redistribución del ingreso para la pequeña y mediana industria. Lo haría mediante dos instrumentos de financiación: el I.A.P.I. y la reforma bancaria de 1946. El primero comercializa la producción agraria, comprando a precios mínimos al productor y vendiendo en un mercado mundial con precios cerealeros altos. La diferencia generada alimenta el crédito oficial. El beneficio alcanza a los pequeños productores que suscriben el crédito rural de habilitación - de bajo interés y largo plazo de reintegro - pero también a estancieros, frigoríficos, compañías inmobiliarias y grandes productores (GIRBAL-BLACHA, 2003). Los parámetros de la política agraria combinan medidas económicas, política de tierras y concesiones laborales para dar respuesta a una creciente presión nacional sobre la tierra que pretende anticiparse a los posibles conflictos entre los diversos sectores rurales y entre ellos y el Estado nacional. El discurso oficial advierte, el de los sectores agrarios reniega de ese avance estatal sobre 
sus intereses, pero ni uno ni otro llevan el enfrentamiento al terreno financiero. El crédito no es un instrumento de confrontación.

En 1949-1950 las condiciones internacionales cambian, bajan los precios agrícolas mundiales ante las abundantes cosechas de Europa, Canadá y Estados Unidos de América del Norte, y la inflación - después de la reforma de la Carta Orgánica del Banco Central (1949) que suprime la restricción en la emisión monetaria - comienza a jaquear la economía argentina. El plan económico peronista muestra sus límites. Los sectores agrarios aprovechan la coyuntura y endurecen sus reclamos obligando al gobierno a definirse. El sistema financiero puesto al servicio del Estado alienta el cambio de rumbo y con éste la vuelta al campo. Se abre otro ciclo en la Nueva Argentina.

La caída de los precios agrícolas mundiales reduce los altos beneficios obtenidos por el I.A.P.I. La economía argentina debe reorientarse. El Estado revisa la doctrinaria tercera posición y su política toma perfiles más liberales. Desde 1948 los términos del intercambio se deterioran y desde 1950 la inversión externa se pondera en otros términos. El discurso gubernamental cambia su lenguaje sin abandonar la confrontación. El pueblo vs. oligarquía, sería reemplazado por el de una sociedad fragmentada en peronistas vs. antiperonistas, obligando a la definición política.

Al inaugurar las sesiones legislativas del $1^{\circ}$ de mayo de 1950, el Presidente Juan Perón advierte que "el sentido de nuestra independencia económica no es de orden aislacionista" y añade - descalificando las críticas opositoras - que "todo cuanto hemos hecho ha sido precisamente para asegurar un promisorio porvenir a la economía agropecuaria" (CÁMARA DE SENADORES DE LA NACIÓN, 1950, p. 14). El nuevo mensaje impregna todo el cuerpo social. "El Presidente de la República, General Juan Perón, aconseja producir más y consumir menos", destaca un libro de lectura para niños de los primeros grados de la escolaridad primaria. El 2do. Plan Quinquenal al alcance de los niños (1953) informa que:

Perón quiere que el campo produzca mucho y que su población humana sea feliz [...] Las asociaciones de campesinos o cooperativas le facilitarán la maquinaria para poder producir más con menos trabajo. El Gobierno fijará los precios más altos a los productos del campo [...] En todas las escuelas se difundirá la benéfica acción del campo. Muchos niños y jóvenes, se dedicarán a las tareas agropecuarias (IANANTUONI, 1953, p. 27).

La economía argentina de los años ‘50 se contrae frente a los cambios coyunturales externos e internos. Los reajustes financieros promueven la inflación y una vez más, la mirada de la dirigencia nacional se dirige al campo, para encontrar allí soluciones rápidas. El I.A.P.I. modifica sustancialmente su operatoria para subsidiar a la producción rural, que con lentitud - después de las sequías de 1951/52 - se recupera. La importación de maquinaria agrícola, los créditos al productor rural y la adquisición de la producción agraria a precios que contrarresten la baja internacional de las cotizaciones incentivan a los productores y forman parte de las estrategias implementadas. El I.A.P.I. se endeuda con el sistema bancario oficial a un 
ritmo vertiginoso: 20.000 millones de pesos al ser liquidado en 1956 (NOVICK, 1986).

Las corporaciones agrarias aprovechan la oportunidad y elevan un Memorial al Presidente Juan Perón refiriéndose a la "situación lesiva del ordenamiento jurídico-económico-social imperante", para intentar favorecer la mecanización agrícola, los precios que reciben los productores por sus materias primas y el cooperativismo agrario orientado a reducir los costos de intermediación (MATEO, 2002). El Presidente despliega "una serie de medidas tendientes a estimular al productor agrario" y reclama a los legisladores su apoyo a "en esta campaña de reactivación agraria". En 1951 reconoce que "lo justo es que ahora la independencia económica sirva al bienestar del campo argentino" (PRESIDENCIA DE LA NACIÓN, 1951, p. 11).

Pero la sequía acentúa la crisis económica. El gobierno debe profundizar sus definiciones, cuando la crisis alcanza su máxima expresión en 1952. Entonces da a conocer el Plan Económico de Emergencia, proponiendo acentuar la producción y reducir el consumo, revisar las disposiciones sobre trabajo rural que impiden a los productores usar sus propios medios de transporte, mientras solicita la colaboración de las organizaciones patronales y obreras para eliminar de los convenios laborales toda circunstancia que limite la producción sin causa justificada (PRESIDENCIA DE LA NACIÓN, 1952). La política de precios agrarios anticipados, los subsidios agrícolas otorgados por el I.A.P.I., la rebaja en dos puntos de las tasas de interés para el crédito agrario y una mayor mecanización de las tareas rurales (Plan trienal desde 1949 para importar tractores e implementos agrícolas) alientan y protegen al sector, mientras se resquebraja la alianza intersectorial que respaldara el ascenso de Juan Perón al poder.

En el primer lustro de la década de 1950, el Estado hace menores concesiones a los asalariados del campo, reduce al mínimo su intervención para entregar la tierra en propiedad a los arrendatarios y concientiza a colonos y pequeños arrendatarios para mejorar los rindes y evitar la erosión del suelo. Acorde con el cambio de rumbo, otros son los destinatarios principales del crédito oficial: frigoríficos, cooperativas agrarias, estancias, empresas productoras e introductoras de maquinaria e instrumental agrícola; quienes reciben préstamos más amplios, reducción en las tasas de interés y créditos de habilitación rural o de fomento (bajo interés y largos plazos) que se dirigen a todo el espectro socio-rural y no sólo a los pequeños productores.

El Segundo Plan Quinquenal (1953-57) consolida esa renovada política agraria. En su capítulo $X$ sobre la acción agraria, propone:

[...] procurar el nivel social, material y cultural de la población rural, consolidando el hogar campesino, estimulando la cordial armonía entre todos los participantes del trabajo rural -productores y obrerosbases esenciales de la economía agraria (PRESIDENCIA DE LA NACIÓN, 1953, sin página)

Las limitaciones en el camino recorrido son reconocidas por el mismo Presidente Juan Perón en la presentación efectuada ante los legisladores del Segundo Plan Quinquenal. Dice entonces que: 
El 1er. Plan Quinquenal realizó fundamentalmente la reforma económica, echando las bases de la Independencia y de la Economía Social, para afianzar la Justicia Social y refirmar la Soberanía Política. El 2do. Plan Quinquenal tiene como objetivo fundamental consolidar la Independencia Económica, para asegurar la Justicia Social y mantener la Soberanía Política (CAMARA DE SENADORES DE LA NACION, 1953, p. 15, grifo nosso).

Los verbos empleados en el discurso - aquí especialmente subrayados - definen tiempos de ajuste para el conjunto de la sociedad argentina, propuestos desde la cúpula gubernativa y partidaria.

La heterogeneidad del peronismo se explicita en las modificaciones económicas que el gobierno de Juan Perón debe introducir para adecuarse a los tiempos, obligándolo a una adaptación del discurso oficial - cada vez más identificado con el partido - corrigiéndose y dando muestras de "profesar una ortodoxia para con los mandatos de la realidad, que suele contrastar con las ortodoxias doctrinarias", según afirmara Arturo Jauretche al asumir su cargo de Presidente del Banco de la Provincia de Buenos Aires durante la gestión del gobernador bonaerense Domingo Mercante (GIRBAL-BLACHA, 1993, p. 3). En estos términos se refuerzan las bases de poder de los grandes propietarios y estancieros, quienes tendrán un papel relevante en el derrocamiento de Perón (setiembre de 1955) y en la política económica implementada por los hombres de la Revolución Libertadora y el desarrollismo liderado por el radical intransigente Arturo Frondizi, después.

\section{Reflexiones a las puertas de la Argentina sojera}

Con el derrocamiento de Juan Perón los sectores populares y la clase media baja quedan desplazados en la distribución del ingreso, en medio de un frágil equilibrio político. Son tiempos de restauración para los grupos dirigentes hechos a un lado por Juan Perón. Priman nuevamente los intereses agropecuarios y la Sociedad Rural Argentina manifiesta su apoyo explícito al gobierno de facto, quien se hace eco de sus reclamos dando lugar a los desalojos y a la libre contratación mediante una nueva ley de arrendamientos rurales. Son decisiones que complementan varias medidas comerciales y financieras en beneficio del agro. Parte de los sectores agrarios se reagrupan y el 18 de setiembre de 1956 se funda CONINAGRO (entidad cooperativa de tercer grado), en tanto cobra fuerza el accionar de los consorcios regionales de experimentación agrícola (CREA) para llevar adelante un esfuerzo rural coordinado. El poder económico agrario se fortalece, toma de decisiones, reclama y se mimetiza con el poder político.

La "segunda revolución agrícola" (COSCIA, 1984), definida por los cambios tecnológicos, avanza. Ya en 1957 con la creación del Instituto Nacional de Tecnología Agropecuaria (I.N.T.A.), se advierte que las sugerencias de la CEPAL a través del Informe Prebisch de 1956, no pasan desapercibidas para el plan neoliberal implementado como refuerzo de la hegemonía agropecuaria tecnificada y recompuesta en favor del comercio exterior argentino (REPUBLICA ARGENTINA, 1979-1980, p. 522). En estos 
nuevos tiempos, el Estado entiende que es "conveniencia nacional" encauzar el comercio de granos por el libre juego de la oferta y la demanda, con respaldo estatal, a través de los "precios sostén" para "asegurar al agricultor su independencia económica" (COSCIA, 1984, p. 59).

Hacia los años de 1960 la reorganización económica apunta a dos cuestiones básicas: el sistema cambiario y el comercio exterior. Se elimina el régimen del control de cambios, la estabilidad económico-financiera pasa a ser regida por la intervención del Banco Central de la República Argentina, se devalúa el peso y se propone la transferencia del ingreso del sector industrial y salarial al agrario. Una progresiva abolición de los controles de precios se conjuga con un sistema de retenciones (dólar agrario) sobre el valor de la exportación de productos agropecuarios (20\% para cereales y semillas y $10 \%$ para carnes vacunas), procurando prevenir una posible caída en los precios externos y evitar que el sector exportador retenga ganancias que alteren el tipo de cambio. El mercado interno paga los costos del ajuste, en medio de la inflación, un elevado endeudamiento externo y costos de producción agropecuaria crecientes que neutralizan parcialmente los beneficios del "precio sostén" y de la reforma cambiaria (BARSKY; GELMAN, 2009, p. 389-425).

El aumento de las exportaciones agrarias sigue siendo básico para equilibrar nuestra balanza de pagos e incrementar la capacidad importadora. Respecto de la agricultura, el principal beneficio recibido por las producciones típicas de la región pampeana, es la diversificación. Se opera la integra- ción al modelo de dependencia tecnológico industrial, las desigualdades interregionales se agudizan y las migraciones internas y de los países limítrofes hacia áreas urbanas engrosan el sector terciario.

Cuando en la segunda mitad de la década del '60 se instala el Estado Burocrático Autoritario, la devaluación del peso acompaña la reforma económico-financiera para nivelar el presupuesto y sanear el gasto público. La agricultura a porcentaje, más diversificada, introduce en el escenario del campo argentino la figura del contratista tantero (por cosecha o por año) entre fines del decenio de los ' 60 y los años ' 70 . El sujeto agrario se desdobla, al separar el propietario de la tierra de aquél que ahora posee el capital, el conocimiento y la tecnología. Ambos componentes (tierra y capital) no se presentan necesariamente unidos. El aumento de la renta agropecuaria y del precio de la tierra fomentan las explotaciones "intensivas" (BALSA, 2006). Se retrae el tamaño de las unidades productivas para ganar en eficiencia y rendimiento. Entre 1960 y 1973 el volumen de cereales y oleaginosas crece a una tasa media de 2,7\% (BARSKY; GELMAN, 2009, p. 427-438).

La desaceleración industrial de las economías centrales, la economía estadounidense (pérdida de competitividad, caída de la productividad, déficit de sus cuentas externas, política monetaria expansiva) y el ascenso en los precios del petróleo, aumentan la oferta financiera para el Tercer Mundo al inicio de los 70, cuando se sacude la estructura mundial de pagos. La disponibilidad de dólares crece. Los términos del intercambio sienten el impacto de esta red de aconteci- 
mientos. La balanza de pagos argentina se alivia ante la disponibilidad de capital externo, en medio de un proceso inflacionario y con tasas reales de interés que son bajas hasta 1982. La suma de estos factores incentiva el endeudamiento argentino. Se diseña un cambio para el agro argentino que abrirá las puertas al país sojero.

Si en los años de 1930 la crisis mundial se origina en los países centrales y se transmite a la periferia, en los primeros años de la década de 1970 la recesión se genera en los países de la OPEP y es mucho más compleja. Durante los años ‘30 la disponibilidad de capitales extranjeros es escasa, en los 70 es considerable. En los ' 30 bajan las cotizaciones de los productos agrícolas y se deterioran los términos del intercambio. Si bien hacia 1970 el volumen de las exportaciones asciende, los términos del intercambio se deterioran más entre 1973-1983 que entre 19291938 (MADDISON, 1988).

La continuidad entre el pretérito y el presente de una Argentina históricamente rural se advierte haciendo un simple repaso de los hitos fundamentales de su pasado. Los protagonistas se vinculan a las etapas de producción y comercialización agraria. La dirigencia argentina se enlaza con el quehacer rural; siendo la adecuación a los tiempos el rasgo que define al sector como dinámico y modernizador para la economía del país.

La Argentina agrícola no rompe los lazos con sus orígenes. De ellos conserva vigente la importancia de la producción típica de la pampa húmeda, ahora diversificada y beneficiada por el avance tecnológico y una mayor eficiencia. También expresa su continuidad a través de la permanencia de cor- poraciones agrarias constituidas en el siglo XIX o en el XX, que suman su acción al de otras más nuevas, formadas como expresión de esa adecuación del sector rural a las condiciones de modernización y globalización actuales. Como manifestación del cambio las unidades productivas mejoran su nivel de eficiencia, acotando superficies y elevando rindes. La tecnología rural se expande, mientras se asiste a una diversificación del mundo agrario, en su cúpula y en sus bases.

El lenguaje de la información pone el acento en la estadística, en la tecnología, mientras se invisibilizan los actores que están detrás de las categorías de análisis y conceptuales. El mercado asume un rol central en su consolidación. La agri-cultura parece desvanecerse frente al agro-negocio, en tanto "forma de una producción gestionada por una serie, por lo general desconocida para la sociedad" (ROJAS VILLAGRA, 2012, p. 17), aunque con su accionar alteren los hábitos socioculturales agrarios.

Las innovaciones avanzan junto con la rentabilidad económica para reconfigurar el sistema de producción agrícola y de alimentos. La tierra en tanto unidad productiva - como se expuso - pierde valor intrínseco frente a la tecnificación rural, la siembra directa, el uso de semillas transgénicas, de fertilizantes, plaguicidas y herbicidas. En suma el granero del mundo sería desplazado por el modelo del agronegocio al amparo de la expansión sojera; una agricultura sin agricultores, que se ven obligados a migrar y abandonar la cultura del trabajo con sus valores intrínsecos. 


\section{Abstract}

Argentinean history is linked to the means, production and rural commercialisation. It is useful to diagnose and understand the Argentinean situation in the international order, knowing and recognising its livestock and commercial origins associated with the agro-export modernity, the limitations of agrarian horizontal expansion and the crisis that lead to economic regulations from the State. The agrarian social parties and the State discuss, irritating a complex power relationships in its changing area. A critical historical track that pays attention to the various areas of rural power, their relationships with each other and with one another and with political power, promotes the reflexion of this study. Although the society has a fragile memory about substantial aspects of its agrarian past, the study leads to understand a nation formed over rural basis.

Keywords: Agriculture. Politics. Territory. Argentina.

\section{Resumo}

A história da Argentina vincula-se ao meio, à produção e à comercialização rural. Conhecer e reconhecer suas origens pecuárias e mercantis, associadas à modernidade agroexportadora, às limitações da expansão horizontal agrária e às crises que induzem a regulação econômica por parte do Estado são úteis para o diagnóstico e a compreensão da situação argentina no contexto internacional. Nessa paisagem mutante, os atores so- ciais agrários e o Estado dialogam e discutem, criando uma complexa relação de poderes. Uma narrativa histórica crítica, que atenda aos diversos setores do poder rural, às relações entre si e entre eles e o poder político, motiva a reflexão deste estudo, que procura compreender uma Nação configurada sobre bases rurais, ainda que a sociedade tenha uma frágil memória sobre aspectos substantivos de seu passado agrário.

Palavras-chave: Agricultura. Política. Território. Argentina.

\section{Referencias}

ANSALDI, Waldo; MORENO, José Luis (Comp.). Estado y sociedad en el pensamiento nacional: antología conceptual para el análisis comparado. Buenos Aires: Cántaro, 1989.

BALSA, Javier. El desvanecimiento del mundo chacarero: transformaciones sociales en la agricultura bonaerense.1937-1988. Bernal: Universidad Nacional de Quilmes, 2006.

BARSKY, Osvaldo; GELMAN, Jorge. Historia del agro argentino: Desde la conquista hasta comienzos del siglo XXI. 3. ed. Buenos Aires: Sudamericana, 2009.

BOTANA, Natalio. El orden conservador: La política argentina entre 1880 y 1916. Buenos Aires: Sudamericana, 1979.

CACIP. CONFEDERACION ARGENTINA DEL COMERCIO, LA INDUSTRIA Y LA PRODUCCION. Actas de la Tercera Conferencia Económica Nacional, 2 al 12 de julio de 1928. Buenos Aires: CACIP, 1928.

CÁMARA DE SENADORES DE LA NACIÓN. Diario de Sesiones. Buenos Aires: HCN, 1950.

CARMAGNANI, Marcelo. Estado y Sociedad en América Latina, 1850-1930. Barcelona: Crítica, 1984. 
COMITÉ NACIONAL DE GEOGRAFIA. Anuario geográfico argentino. Buenos Aires, 1941. p. 203-204.

COSCIA, Adolfo. La segunda revolución agrícola en la región pampeana. Buenos Aires: C.A.D.I.A., 1984.

GIRBAL-BLACHA, Noemí. Acerca de la vigencia de la Argentina agropecuaria. Estado y crédito al agro durante la gestión peronista (1946-1955). The Americas, Wáshington, v. 56, n. 3, p. 77-102, Jan. 2000.

- Estado, chacareros y terratenientes (1916-1930): Política agraria y relaciones de poder. Buenos Aires: Centro Editor de América Latina, 1988.

Historia del Banco de la Provincia de Buenos Aires: Gestión del Doctor Arturo Jauretche (1946-1950). Buenos Aires: Banco de la Provincia de Buenos Aires, 1993.

. Mitos, paradojas y realidades en la Argentina peronista (1946-1955): una interpretación histórica de sus decisiones político-económicas. Buenos Aires: Universidad Nacional de Quilmes, 2003. HORA, Roy. Los terratenientes de la pampa argentina: una historia social y política, 1860-1945. Buenos Aires: Siglo XXI, 2003.

IANANTUONI, Domingo. 2do. Plan quinquenal al alcance de los niños Buenos Aires: Luis Lasserre, 1953.

LATTUADA, Mario. La política agraria peronista (1943-1983). Buenos Aires: CEAL, 1986.

LLACH, Juan José. El Plan Pinedo de 1940, su significado histórico y los orígenes de la economía política del peronismo. Desarrollo Económico, Buenos Aires, v. 23, n. 92, p. 515-558, enero/ marzo 1984.

MADDISON, Angus. Dos crisis: América y Asia 1929-1938 y 1973-1983. México: FCE, 1988.

MANUAL del Peronista. Buenos Aires, 1948.

MATEO, Graciela. La Asociación de Cooperativas Argentinas como centro generador de servicios sociales. In: CONGRESO DE LA
ASOCIACIÓN LATINOAMERICANA DE SOCIOLOGÍA RURAL, 6, 2002, Porto Alegre. Atas... Porto Alegre: Ufrgs, 2002. 1 CD.

MCGANN, Thomas. Argentina, Estados Unidos y el sistema interamericano. 1880-1914. Buenos Aires: Eudeba, 1960.

NOVICK, Susana. I.A.P.I.: auge y decadencia. Buenos Aires: CEAL, 1986.

O'CONNELL, Arturo. La Argentina en la depresión: los problemas de una economía abierta. Desarrollo Económico, Buenos Aires, v. 23, n. 92, p. 479-514, enero/marzo 1984.

ORTIZ, Ricardo. Historia económica de la Argentina, 1850-1930. Buenos Aires: Plus Ultra, 1964. t. 2.

PRESIDENCIA DE LA NACIÓN. 2do Plan quinquenal. Buenos Aires: Subsecretaría de Informaciones, 1953.

. El campo recuperado por Perón 1944-

1951. Buenos Aires: Subsecretaría de Informaciones, 1951.

. Plan de Emergencia Económica 1952.

Buenos Aires: Subsecretaría de Informaciones, 1952.

REPUBLICA ARGENTINA. Anuario Estadístico de la República Argentina, 1979-1980. Buenos Aires, 1979-1980.

ROCK, David. El radicalismo argentino, 18901930. Buenos Aires: Amorrortu, 1997.

ROJAS VILLAGRA, Luis. Actores del agronegocio en Paraguay. Asunción: BASE-ICCO-Diakonia, 2012.

SCOBIE, James. Revolución en las pampas: Historia Social del trigo argentino, 1860-1910. Buenos Aires: Solar, 1968.

SMITH, Peter. Carne y política en la Argentina. Buenos Aires: Paidós, 1968. 